\title{
Cytolytic action of Vibrio vulnificus haemolysin on mast cells from rat peritoneal cavity
}

\author{
H. YAMANAKA, K. SUGIYAMA*, H. FURUTA*, S. MIYOSHI and S. SHINODA
}

Department of Environmental Hygienic Chemistry, Faculty of Pharmaceutical Sciences, Okayama University, 1-1-1 Tsushima-Naka, Okayama 700, and "Department of Pharmacology, Okayama University Dental School, 2-5-1 Shikata-cho, Okayama 700, Japan

\begin{abstract}
Summary. The mode of action of Vibrio vulnificus haemolysin (VVH) on mast cells from the peritoneal cavity of the rat was examined. VVH induced histamine release, and damage to the mast cells, in a dose-dependent fashion. When $1 \mu \mathrm{g}$ of VVH was added to $c .10^{5}$ mast cells at $37^{\circ} \mathrm{C}$, histamine release was observed after a lag period of 5-10 s, and was complete within $5 \mathrm{~min}$. The action was temperature-dependent, and was not induced at $4^{\circ} \mathrm{C}$. Disodium cromoglycate, a membrane stabiliser for mast cells, inhibited the histamine release significantly, but the effect was not dosedependent. Moreover, leakage of lactate dehydrogenase from VVH-treated mast cells was observed. These results suggest that VVH acts on the cell membrane of mast cells and is cytolytic.
\end{abstract}

\section{Introduction}

Vibrio vulnificus is a halophilic marine vibrio, ${ }^{1,2}$ associated with well-characterised disease ${ }^{3}$ including wound infection, septicaemia and other infections. $^{4,5}$ Septicaemia is commonly induced in persons with pre-existing disease such as liver damage, immune deficiency syndromes, or haemochromatosis. $^{6,7}$ The infection caused by this bacterium has attracted special interest because of its high mortality. ${ }^{8}$ Fever, chill, nausea, vomiting and severe skin lesions have been reported. ${ }^{9}$ Erythema, bullae, necrotic ulcer, cellulitis and oedema may occur. $^{10,11}$

We have proposed that a protease exotoxin produced by $V$. vulnificus may be related to the pathogenicity, including the production of skin lesions, ${ }^{12}$ because the protease degrades collagen, elastin and casein ${ }^{13}$ and enhances vascular permeability. ${ }^{14,15}$

On the other hand, it was shown that a 56-Kda cytolysin (haemolysin), another exotoxin produced by this vibrio, enhanced vascular permeability, and had a cytopathic effect on Chinese hamster ovary cells, and lethal activity in mice $;^{16}$ and Gray and Kreger ${ }^{17}$ have reported that it induced mouse skin damage. $W \mathrm{e}^{18}$ have isolated a $V$. vulnificus haemolysin (VVH), with the same biological activities, from strain B3547, although its molecular weight $(50 \mathrm{Kda})$ was slightly less than that of the above

Received 15 May 1989; revised version accepted 30 Oct. 1989. cytolysin. The enhancement of vascular permeability by VVH in the dorsal skin of the rat was inhibited by the addition of diphenhydramine, an antihistamine (unpublished observation). Therefore, we suspected that VVH may affect mast cells, which contain much histamine; and we report here the effect of VVH on mast cells from the peritoneal cavity of the rat.

\section{Materials and methods}

\section{Purification of $V$. vulnificus haemolysin (VVH)}

VVH was purified from the culture supernate of a virulent strain (CDC B3547) of V.vulnificus as previously described. ${ }^{18}$

\section{Isolation of mast cells}

Mast cells were collected from the peritoneal cavities of male Wistar rats $(300-400 \mathrm{~g})$ and purified by use of Percoll (Sigma). ${ }^{19}$ The mast cells, $c$. $(1-3) \times 10^{5} / \mathrm{ml}$, were suspended in phosphate-buffered saline (PBS) consisting of $154 \mathrm{mM} \mathrm{NaCl}, 2.7 \mathrm{mM} \mathrm{KCl}, 0.9 \mathrm{mM} \mathrm{CaCl}, 6.7 \mathrm{mM}$ $\mathrm{KH}_{2} \mathrm{PO}_{4}-\mathrm{Na}_{2} \mathrm{HPO}_{4}(\mathrm{pH} 7 \cdot 2)$ and bovine serum albumin $0.01 \%$. The purity of the mast cells thus obtained was more than $90 \%$, as assessed by microscopy.

\section{Measurement of histamine release from mast cells treated with $V V H$}

For histamine release, a suspension of $c .10^{5}$ mast cells in $0.5 \mathrm{ml}$ of PBS was incubated with various amounts of 
VVH for $10 \mathrm{~min}$ at $37^{\circ} \mathrm{C}$. The reaction was then terminated by addition of $1.5 \mathrm{ml}$ of ice-cold PBS. The mixture was centrifuged at $1000 \mathrm{~g}$ for $10 \mathrm{~min}$ at $4^{\circ} \mathrm{C}$. The histamine in the supernates and the precipitates was measured by the method of Shore et al. ${ }^{20}$ Histamine release, in the supernate, was calculated as the percentage of the total histamine in the system. For study of the kinetics of histamine release, VVH was added to the cell suspension and incubated for $5 \mathrm{~min}$ at $37^{\circ} \mathrm{C}$; the reaction was terminated after various periods by addition of icecold PBS.

\section{Mode of action of VVH on mast cells}

Activity of lactate dehydrogenase (LDH), which is contained in the cytosol of mast cells, was determined by the fluorimetric method of Roy et al. ${ }^{21}$ to study whether VVH would induce cytolysis. If it does, $\mathrm{LDH}$ release is detectable in the reaction mixture; and this was estimated in relation to the fluorescence intensity obtained by addition of Triton X-100 $0.01 \%$ to (4-6) $\times 10^{5}$ mast cells. To determine the effect of membrane stability in the histamine release, disodium cromoglycate (Sigma; 2$50 \mu \mathrm{M})$ was used. Also, the morphological changes of mast cells treated with VVH were observed by phasecontrast microscopy. The action of compound 48/80 (Sigma), a chemical agent which induces a typical degranulation of mast cells, was compared with that of VVH.

All experiments were performed in duplicate or triplicate; mean values are shown.

\section{Results}

\section{Histamine release from mast cells treated with $\mathrm{VVH}$}

VVH induced histamine release from isolated mast cells in a dose-dependent manner. The amount of VVH that induced $50 \%$ release from $c .10^{5}$ cells was $c .0 \cdot 2 \mu \mathrm{g}$ (fig. 1). After VVH had been heated at $60^{\circ} \mathrm{C}$ for $10 \mathrm{~min}$, its haemolytic activity disappeared, and histamine release was not observed.

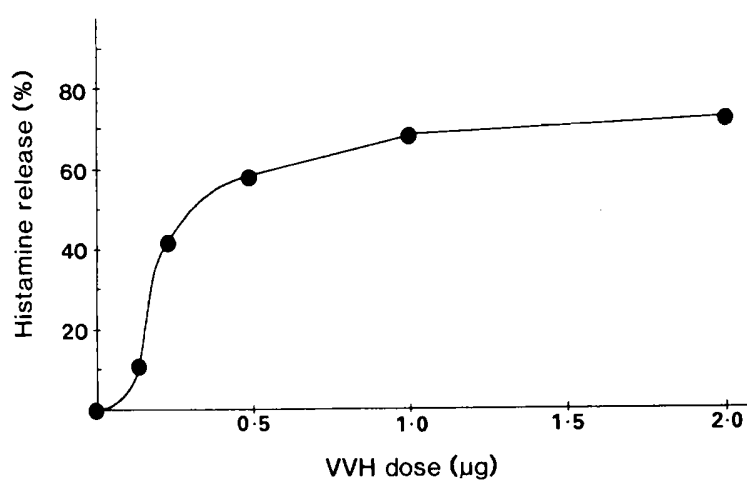

Fig. 1. Histamine release from $c .10^{5}$ mast cells treated with various doses of $\mathrm{VVH}$ and incubated for $10 \mathrm{~min}$ at $37^{\circ} \mathrm{C}$.

\section{Duration of histamine release}

The release of histamine from mast cells treated with VVH was induced rapidly at $37^{\circ} \mathrm{C}$ after a short lag-period of 5-10 s (fig. 2), and the maximal release was reached within $5 \mathrm{~min}$.

\section{Influence of temperature on the action of $V V H$}

Histamine release from mast cells treated with VVH was temperature dependent (fig. 3). No release was detected at $4^{\circ} \mathrm{C}$; action was induced at $15^{\circ} \mathrm{C}$, was greater at $37^{\circ} \mathrm{C}$, but diminished at $45^{\circ} \mathrm{C}$.

\section{Mode of action of VVH on mast cells}

A previous report ${ }^{21}$ suggested that histamine release by a small amount of compound $48 / 80$ was not accompanied by the leakage of $\mathrm{LDH}$ contained in the cytosol of mast cells, and there was no cytolysis.

Histamine release induced by VVH was accompanied by the leakage of LDH (fig. 4). Moreover, it

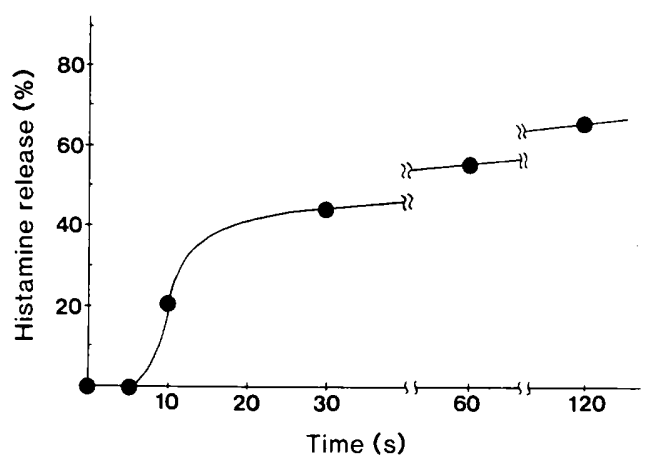

Fig. 2. Duration of histamine release from $c .10^{5}$ mast cells, induced by $1 \mu \mathrm{g}$ of $\mathrm{VVH}$ at $37^{\circ} \mathrm{C}$.

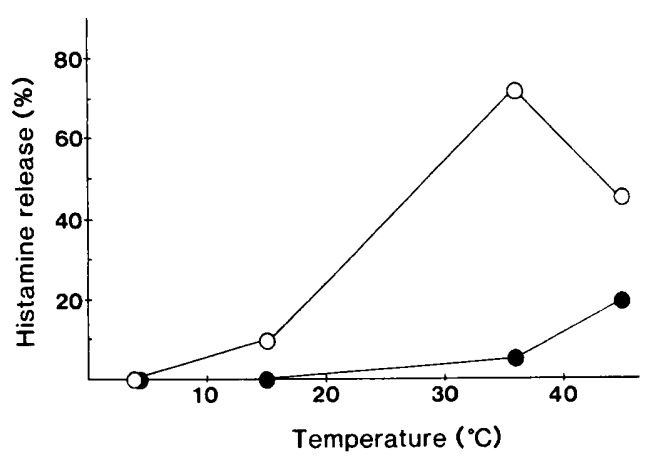

Fig. 3. Influence of temperature on histamine release from $c .10^{5}$ mast cells pre-incubated at various temperatures for $5 \mathrm{~min}$, and incubated for a further $10 \mathrm{~min}$ with $1 \mu \mathrm{g}$ of VVH (O) or without VVH (O). 


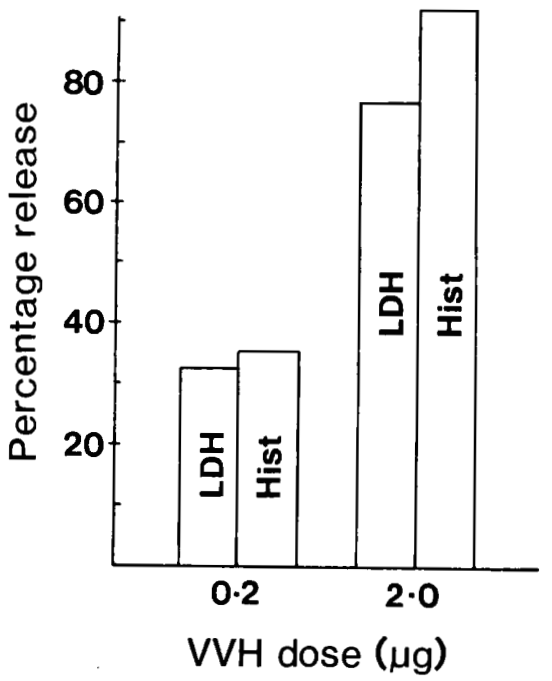

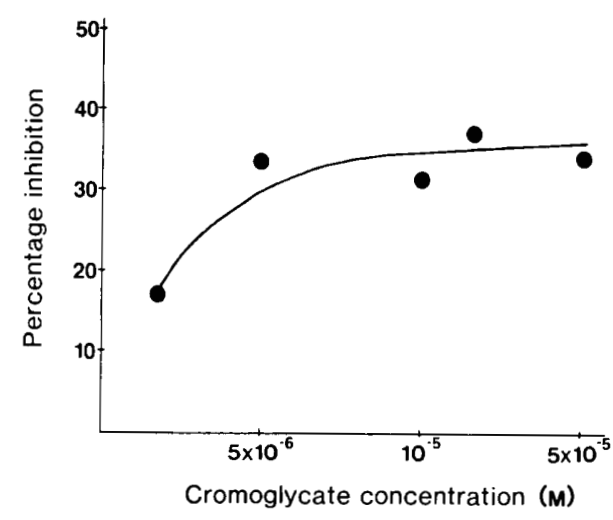

Fig. 5. Effect of pre-incubation with various doses of disodium cromoglycate on the action of $1 \mu \mathrm{g}$ of $\mathrm{VVH}$ on $c .10^{5}$ mast cells. The maximal inhibition of histamine release was only c. $35 \%$.

Fig. 4. Release of histamine (Hist.) and lactate dehydrogenase $(\mathrm{LDH})$ from $c .5 \times 10^{5}$ mast cells incubated with $\mathrm{VVH}$ at $37^{\circ} \mathrm{C}$ for $10 \mathrm{~min}$.

A

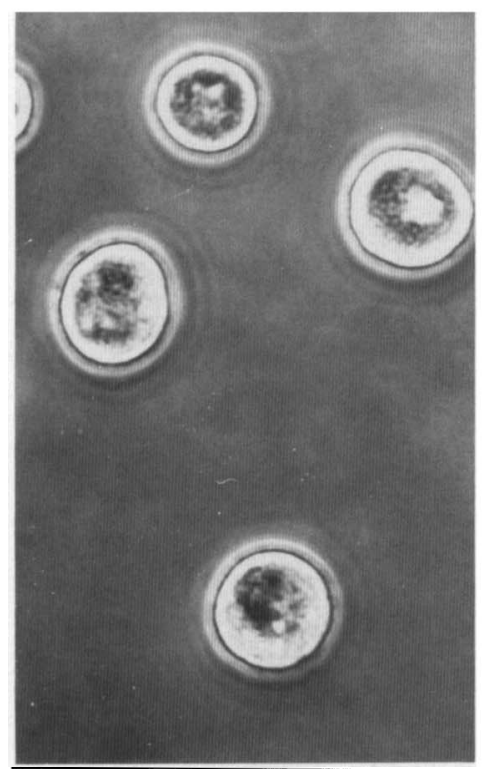

B

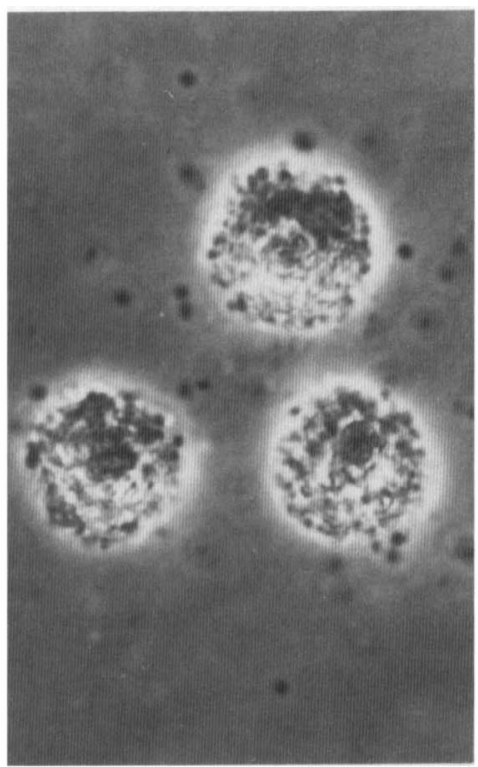

C

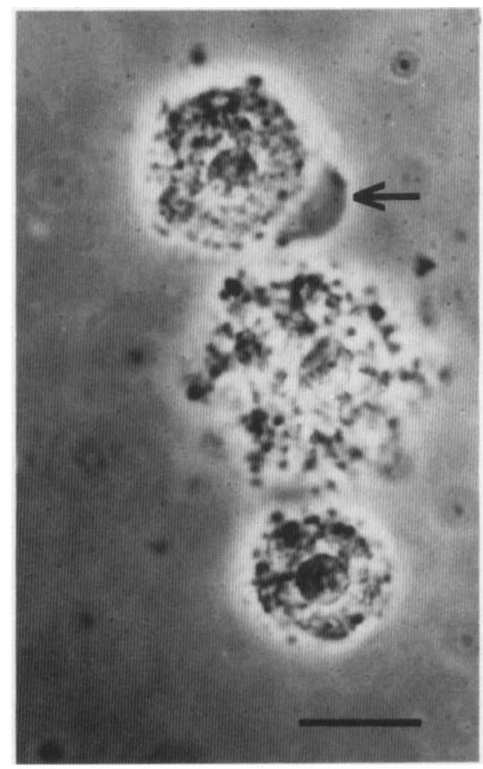

Fig. 6. Phase-contrast micrographs of mast cells (A) before treatment, (B) after treatment with $0 \cdot 5 \mu \mathrm{g}$ of compound $48 / 80,(C)$ after treatment with $2 \mu \mathrm{g}$ of VVH. Blisters were often observed from the action of VVH (arrow). Bar $=20 \mu \mathrm{m}$.

was inhibited to some extent by prior administration of disodium cromoglycate, thought to be a membrane stabiliser of mast cells. But the inhibitory effect was not related directly to the drug concentration (fig. 5), and reached a maximum of only $c .35 \%$ inhibition. The morphological changes of mast cells treated with VVH are shown in fig. 6. The cytolytic effect of VVH was compared with the action of compound $48 / 80$ which induced a typical degranu- lation after exocytosis of the cells. Furthermore, the formation of blisters was observed in VVH action, although the meaning of this observation is not clear.

\section{Discussion}

It has been shown that VVH induces histamine release from isolated peritoneal mast cells of the 
rat, concurrently with cytolytic action. It is thought that VVH has direct action on mast cells; heatdenatured VVH did not induce histamine release. The response to VVH was temperature dependent; it was not detected at $4^{\circ} \mathrm{C}$, it increased up to $37^{\circ} \mathrm{C}$, but was reduced at $45^{\circ} \mathrm{C}$-perhaps because of the stabilising effect on mast cells of temperatures of $40-50^{\circ} \mathrm{C}^{22}$ A lag-period was observed in the initial response of mast cells to VVH. In haemolysis by $\mathrm{VVH}$ also, a lag-period is observed in $\mathrm{K}^{+}$release from erythrocytes. ${ }^{18} \mathrm{We}$ suppose that time may be needed for binding of VVH to the erythrocyte membrane, to form lesions, and likewise in the action of VVH on mast cells before histamine release. Maximal histamine release by compound $48 / 80^{23}$ or dynorphin ${ }^{22}$ (with which degranulation leads to histamine release) is reached within $10 \mathrm{~s}$ and a lag-period is not detected. Therefore, we suggested that the mechanism of histamine release by VVH may be different.

Histamine release by VVH was accompanied by the leakage of $\mathrm{LDH}$, indicating that $\mathrm{VVH}$ induced cytolysis; and this suggestion was supported by the microscopic observations. Disodium cromoglycate has been shown to inhibit the exocytosis of mast cells stimulated with various agents such as anti-

\section{REFERENCES}

1. Tison D L, Kelly M T. Vibrio species of medical importance. Diagn Microbiol Infect Dis 1984; 2 : 263-276.

2. Janda J M, Powers C, Bryant R G, Abbott S L. Current perspectives on the epidemiology and pathogenesis of clinically significant Vibrio spp. Clin Microbiol Rev $1988 ; 1: 245-267$.

3. Klontz K C, Lieb S, Schreiber M, Janowski H T, Baldy L M, Gunn R A. Syndromes of Vibrio vulnificus infections. Clinical and epidemiological features in Florida cases 1981-1982. Ann Intern Med 1988; 109 : 318-323.

4. Blake P A, Weaver R E, Hollis D G. Diseases of humans (other than cholera) caused by vibrios. Ann Rev Microbiol 1980; 34: 341-367.

5. Tacket C O, Brenner F, Blake P A. Clinical features and an epidemiological study of Vibrio vulnificus infections. $J$ Infect Dis $1984 ; 149$ : 558-561.

6. Shirouzu K, Miyamoto Y, Yasaka T, Matsubayashi Y, Morimatsu M. Vibrio vulnificus septicaemia. Acta Pathol Jpn 1985; 35: 731-739.

7. Ito H, Kaetsu M, Saeki Y et al. A saved case of Vibrio vulnificus infection with shock, DIC and necrotizing fasciitis. Kansenshogaku Zasshi 1986; 60: 695-700 (in Japanese).

8. Morris J G. Vibrio vulnificus - a new monster of the deep? Ann Intern Med 1988; 109: 261-263.

9. Baethge B A, West B C. Vibrio vulnificus: did Hippocrates describe a fatal case? Rev Infect Dis 1988; 10: 614-615.

10. Tyring S K, Lee P C. Hemorrhagic bullae associated with Vibrio vulnificus septicemia. Report of two cases. Arch Dermatol 1986; 122 : 818-820. gen, ${ }^{24}$ compound $48 / 80,{ }^{23,25,26}$ dextran, ${ }^{27}$ neuroten $\sin ^{28}$ and dynorphin. ${ }^{22}$ The histamine release by VVH was slightly inhibited by disodium cromoglycate, but this inhibition was not dosedependent, and the maximal effect was $35 \%$ reduction. Disodium cromoglycate may have a stabilising effect on the mast cell membrane, ${ }^{19,23,25}$ and it may affect VVH action because the latter acts directly on the target membrane.

It has been reported that many other bacterial haemolysins act not only on various erythrocytes but also on other mammalian cells. ${ }^{29-32}$ The present findings suggest that VVH degrades mast cells and induces histamine release. Therefore, it seems that VVH, as well as V. vulnificus protease, is involved in oedema formation, haemoconcentration and other skin manifestations in V. vulnificus infection. Furthermore, it was observed that VVH possessed cytolytic activity on leucocytes (data not shown), as described by Gray and Kreger $;{ }^{17}$ therefore, it may have an important role in $V$. vulnificus infection.

This research was supported by a Grant-in-Aid for Scientific Research from the Ministry of Education Science and Culture of Japan, and by the Japan Society for the Promotion of Science for Japanese Junior Scientists.

11. Chin K P, Lowe M A, Tong M J, Koehler A L. Vibrio vulnificus infection after raw oyster ingestion in a patient with liver disease and acquired immune deficiency syndrome-related complex. Gastroenterol 1987; $92: 796-799$.

12. Miyoshi S, Shinoda S. Role of the protease in the permeability enhancement by Vibrio vulnificus. Microbiol Immunol 1988; 32: 1025-1032.

13. Miyoshi N, Shimizu C, Miyoshi S, Shinoda S. Purification and characterization of Vibrio vulnificus protease. Microbiol Immunol 1987; 31 : 13-25.

14. Miyoshi S, Sugiyama K, Suzuki Y, Furuta H, Miyoshi N, Shinoda S. Enhancement of vascular permeability due to histamine-releasing effect of Vibrio vulnificus protease in rat skin. FEMS Microbiol Lett 1987; 40: 95-98.

15. Miyoshi N, Miyoshi S, Sugiyama K, Suzuki Y, Furuta H, Shinoda S. Activation of the plasma kallikrein-kinin system by Vibrio vulnificus protease. Infect Immun 1987; 55: $1936-1939$.

16. Kreger A, Lockwood D. Detection of extracellular toxin(s) produced by Vibrio vulnificus. Infect Immun 1981; 33: 583-590.

17. Gray L D, Kreger A S. Mouse skin damage caused by cytolysin from Vibrio vulnificus and by $V$. vulnificus infection. $J$ Infect Dis $1987 ; 155$ : 236-241.

18. Yamanaka H, Satoh T, Katsu T, Shinoda S. Mechanism of haemolysis by Vibrio vulnificus haemolysin. J Gen Microbiol 1987; 133 : 2859-2864.

19. Wells E, Mann J. Phosphorylation of a mast cell protein in response to treatment with anti-allergic compounds. Implications for the mode of action of sodium cromoglycate. Biochem Pharmacol 1983; 32 : 837-842. 
20. Shore P A, Burkhalter A, Cohn V H. A method for the fluorometric assay of histamine in tissues. $J$ Pharmacol Exp Ther 1959; 127: 182-186.

21. Roy P D, Moran D M, Bryant V, Stevenson R, Stanworth D R. Further studies on histamine release from rat mast cells in vitro induced by peptides. Biochem $J 1980$; 191 : 233-237.

22. Sugiyama K, Furuta $H$. Histamine release induced by dynorphin-(1-13) from rat mast cells. Jpn J Pharmacol $1984 ; 35$ : 247-252.

23. Orr T S, Hall D E, Gwilliam J M, Cox J S G. The effect of disodium cromoglycate on the release of histamine and degranulation of rat mast cells induced by compound 48-80. Life Sci 1971; 10: 805-812.

24. Garland L G. Effect of cromoglycate on anaphylactic histamine release from rat peritoneal mast cells. $\mathrm{Br} J$ Pharmacol 1973; 49: 128-130.

25. Spataro A C, Bosmann H B. Mechanism of action of disodium cromoglycate on mast cell calcium ion influx after a histamine-releasing stimulus. Biochem Pharmacol 1976; 25 : 505-510.

26. Lagunoff D, Martin T W, Read G. Agents that release histamine from mast cells. Annu Rev Pharmacol Toxicol $1983 ; 23: 331-351$.

27. Garland L G, Mongar J L. Inhibition by cromoglycate of histamine release from rat peritoneal mast cells induced by mixtures of dextran, phosphatidyl serine and calcium ions. Br J Pharmacol 1974; 50: 137-143.

28. Carraway R, Cochrane D E, Lansman J B, Leeman S E, Paterson B M, Welch H J. Neurotensin stimulates exocytotic histamine secretion from rat mast cells and elevates plasma histamine levels. J Physiol (Lond) $1982 ; 323$ : 403-414.

29. Stephen J, Pietrowski R A. Bacterial toxins, 2nd edn (Aspects of Microbiology 2). American Society for Microbiology, Washington DC. 1986.

30. Suttorp N, Seeger W, Zucker-Reimann J, Roka L, Bhakdi S. Mechanism of leukotriene generation in polymorphonuclear leukocytes by staphylococcal alpha-toxin. Infect Immun 1987; 55: 104-110.

31. Howell T W, Gomperts B D. Rat mast cells permeabilised with streptolysin $\mathrm{O}$ secrete histamine in response to $\mathrm{Ca}^{2+}$ at concentrations buffered in the micromolar range. Biochim Biophys Acta 1987; 927 ; 177-183.

32. Scheffer J, Konig W, Braun V, Goebel W. Comparison of four hemolysin-producing organisms (Escherichia coli, Serratia marcescens, Aeromonas hydrophila and Listeria monocytogenes) for release of inflammatory mediaters from various cells. J Clin Microbiol 1988; 26 : 544-551. 